\title{
Serum placental-like alkaline phosphatase (PLAP): a novel combined enzyme linked immunoassay for monitoring ovarian cancer
}

\author{
J FISKEN*, R C F LEONARD, G SHAW, * A BOWMAN, J E ROULSTON* \\ From the University Departments of *Clinical Chemistry and Clinical Oncology, Royal Infirmary, Edinburgh
}

SUMMARY A new combined enzyme linked immunoassay (ELISA) was developed to measure both serum placental-like alkaline phosphatase (PLAP) activity (PLAP A) and concentration (PLAP C) in the same microtitre plate using an Imperial Cancer Research Fund monoclonal antibody, designated H17E2. PLAP A and PLAP C were determined together with an existing marker, CA125, in 397 serial samples from 87 patients with epithelial ovarian cancer. Retrospective assessment showed the sensitivity to increase from $73 \%$ with CA125 alone, to $88 \%$ using CA125 and PLAP A, and to $93 \%$ with all three markers in 261 samples from the patients with known active disease at the time of sampling. When the results for all 397 samples were included in the analysis, however, the specificity, sensitivity, accuracy and predictive powers of this monoclonal antibody were not sufficiently high to assist in the prospective follow up of patients with ovarian cancer. This was due to a significant number of false positive and false negative results.

Our data indicate that PLAP A or PLAP C estimation with H17E2 may, therefore, only be of value in the management of those patients with known active disease who are already known to be "marker positive" for this antigen.

Ovarian cancer produces few local symptoms and presents late in most cases; consequently the mortality is high. Attempts to improve the detection of early stage disease have foundered on the lack of a reliable clinical or radiological screening test. In the past five years screening work has focused on the identification of serological tumour markers which could facilitate earlier diagnosis and disease monitoring, a vital step towards improving the survival of these patients. Although numerous tumour markers have been identified to date, ${ }^{1}$ none is specific enough to warrant its use as a primary diagnostic tool, but several have proved useful for monitoring the course of disease. ${ }^{2}$ Since the publication of the initial report by Bast et al, ${ }^{3}$ CA125 has become the accepted test with which other markers are compared.

There has been considerable interest shown recently in the application of placental-like alkaline phosphatase (PLAP) as a marker of epithelial ovarian cancer (EOC). Ectopic expression of PLAP was first discovered in a patient with squamous cell carcinoma of the lung ${ }^{4}$ and has subsequently been found in

Accepted for publication 4 August 1988 various malignancies ${ }^{5}$ including ovarian cancer. Raised serum concentrations of this oncofetal antigen have been found in $44 \%,{ }^{5} 35 \%,{ }^{6}$ and $40 \%{ }^{7}$ of patients with ovarian cancer.

PLAP is normally produced by the syncytiotrophoblast of the placenta and has been detected in sera as early as 9 weeks' gestation, increasing considerably during the second half of pregnancy. ${ }^{8}$ It is normally undetectable in the sera of healthy subjects and it is this difference between normal adults and patients with cancer which affords it marker potential. Smoking, however, is an established cause of false positive results.'

Serum PLAP activity (PLAP A) and concentration (PLAP C) were determined in 387 healthy volunteers and 397 serial samples from 87 patients using a novel combined enzyme linked immunoassay (ELISA), developed by modification of two existing separate assays for PLAP A ${ }^{10}$ and PLAP C. ${ }^{11}$ Serum CA125 was also determined in all samples and evaluated with PLAP A and PLAP C in the patients with ovarian cancer. Both PLAP A and PLAP C were measured to investigate a recent report ${ }^{11}$ that PLAP A decreased and PLAP C increased simultaneously with progression of disease. 
Subjects and methods

The Imperial Cancer Research Fund (ICRF) murine monoclonal antibody H17E2 used in this study was produced by immunisation with term placental membranes. ${ }^{12}$ It reacts with a heat stable alkaline phosphatase that is more resistant to inhibition by L-Leu than Phe-Ala-Gly-Gly, confirming its recognition of term PLAP as opposed to other isoenzymes of the same family. ${ }^{12}$

Three hundred and ninety seven serial blood samples were collected from 87 patients with EOC over three years. The samples were separated by centrifugation at $1500 \mathrm{~g}$ for $10 \mathrm{~min}$ at $20^{\circ} \mathrm{C}$ and each serum sample stored in $0.5 \mathrm{ml}$ portions at $-20^{\circ} \mathrm{C}$. Each sample was thawed once and assayed for PLAP A and PLAP C. A separate portion was assayed for CA125 using CIS ELSA-CA kits (CIS (UK) Ltd, High Wycombe, Buckinghamshire).

Upper limits of normal, defined as the 95th centile for PLAP A and PLAP C were established by assaying samples from 387 healthy blood donors after obtaining informed consent. Smoking habits were noted. All samples were tested in duplicate using a near term pregnancy serum pool as quality control material.

\section{COMBINED PLAP A AND C ELISA}

MicroELISA plates (M129B, Dynatech, Billingshurst, Kent) were coated overnight at $4^{\circ} \mathrm{C}$ with $100 \mu \mathrm{l} /$ well $1.0 \mu \mathrm{g} \mathrm{ml}^{-1} \mathrm{H} 17 \mathrm{E} 2$ monoclonal antibody (supplied by courtesy of the ICRF, Lincoln's Inn Fields, London) in $50 \mathrm{mM}$ carbonate buffer, $\mathrm{pH} 9 \cdot 6$. The plates were washed three times in $0.15 \mathrm{M}$ phosphate buffered saline (PBS), $\mathrm{pH} 7 \cdot 4$, containing $0.05 \% \mathrm{v} / \mathrm{v}$ Tween 20 (PBS/Tween 20) to remove unbound antibody; $100 \mu \mathrm{l}$ serum were then added and incubated for two hours at room temperature. After washing four times in PBS/ Tween $20100 \mu \mathrm{l}$ phosphatase substrate: $5 \mathrm{mmol} \mathrm{1}^{-1}$ disodium p-nitrophenylphosphate (Sigma, Poole, Dorset) in $0.2 \mathrm{mmol} \mathrm{1}^{-1}$ diethanolamine buffer (BDH, Glasgow, Scotland) containing $0.5 \mathrm{mmoll}^{-1} \mathrm{MgCl}_{2}$ (pH 9.8) were added and incubated for two hours at $37^{\circ} \mathrm{C}$. Optical density was measured at $405 \mathrm{~nm}$ using a Titertek Multiskan MCC/340 spectrophotometer (Flow Laboratories, Irvine, Scotland) to determine PLAP A. The plates were then washed four times and $100 \mu \mathrm{l}$ rabbit anti-human PLAP (Dakopatts, Denmark) at $1 / 250$ dilution in PBS containing $0.5 \% \mathrm{w} / \mathrm{v}$ bovine serum albumin (BSA) were added and incubated for 30 minutes at room temperature. After washing three times in PBS/Tween $20100 \mu$ l peroxidase-conjugated goat anti-rabbit IgG (Sigma, Poole, Dorset) at $1 / 1000$ dilution in $\mathrm{PBS} / 0.5 \% \mathrm{BSA}$ were added and incubated for 30 minutes at room temperature. The plates were finally washed three times and incubated at room temperature for $\mathbf{4 5}$ minutes with $100 \mu$ l peroxidase substrate: $0.04 \% \mathrm{w} / \mathrm{v}$ ophenylenediamine and $0.012 \% \mathrm{v} / \mathrm{v}_{2} \mathrm{H}_{2}$ in $0.15 \mathrm{M}$ citrate-phosphate buffer (pH 5.0) $\mathrm{H}_{2} \mathrm{SO}_{4}(50 \mu \mathrm{l} 2.5 \mathrm{M})$ were added to stop the reaction and PLAP concentration determined by measuring optical density at $492 \mathrm{~nm}$ using a Titertek Multiskan MCC/340.

All patient samples were scored true or false by correlating the clinical state at the time of sampling with the antigen titre. Presence of disease was defined on clinical, radiological, or surgical grounds (laparotomy). Clinical disease activity was defined temporally as declared disease progression or reactivated disease within six months of assay. From this the sensitivity, specificity, accuracy and predictive values of PLAP were determined, alone and in combination with CA125.

\section{DisCRETE PLAP C ASSAY}

PLAP C was determined separately to show that preincubation with phosphate substrate for the activity assay did not have any deleterious effects on subsequent PLAP C assay performance in the combined assay.

The plates were coated in the same manner as in the combined assay. After the serum incubation step the plates were washed three times and rabbit anti-human PLAP added. The remainder of the assay was identical with that of the combined concentration assay.

\section{Results}

\section{ASSAY PERFORMANCE}

The correlation between the combined and discrete PLAP C assay was high $(\mathrm{n}=34, \mathrm{r}=0.97, \mathrm{y}=1.4 \mathrm{x}$, $p<0.001$ ) (fig 1 ), supporting the use of a combined assay.

Based on results from the near term pregnancy serum pool, the between $(n=160)$ and within $(n=46)$ assay coefficients of variation were: $16 \%$ and $7 \cdot 5 \%$ for PLAP A assay, $8.2 \%$ and $3.8 \%$ for combined PLAP C assay, and $13 \%$ and $4.4 \%$ for discrete PLAP C assay, respectively.

\section{CORRELATION BETWEEN PLAP A AND C IN} BLOOD DONORS

Using the results from 397 blood donors, PLAP A and $C$ were poorly associated $(n=387, r=0.56$, $y=0.16 x, p<0.001)$, although still significantly correlated.

PLAP A did not seem to be influenced by smoking in either male or female blood donors $(p>0.05)$. PLAP C, however, did seem to be increased by smoking in both male and female donors $(p<0.001)$.

REFERENCE RANGE FOR PLAP A AND C

PLAP A and PLAP C were not normally distributed in 


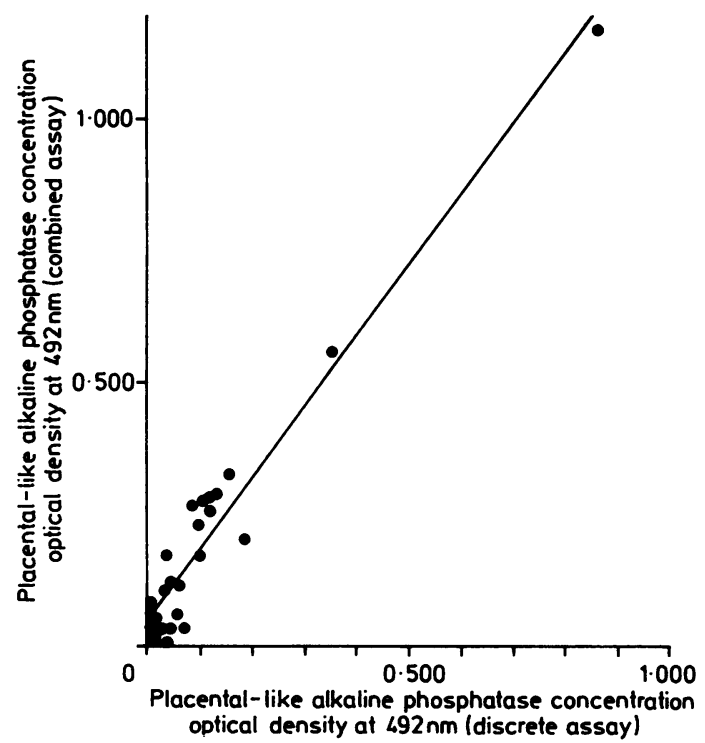

Fig 1 Correlation between PLAP concentration measured alone and after activity in combined technique.

the control population, neither did they normalise following logarithmic transformation as tested by Kolmogorov-Smirnov Goodness of Fit Test $(p<0.05)$. Therefore, the 95th centiles of the control population, 0.400 and 0.085 for PLAP A and PLAPC, respectively, were used as cut off values. In smokers, however, the 95th centile of the PLAP C reference interval was 0.185; for PLAP A it was unchanged from the non-smokers' value. Therefore, PLAP C abnormality was defined as a value greater than halfway between the 95th centile for non-smokers and smokers because the smoking habits were known in only $10 \%$ of the patient population. Assigned cut off values were therefore 0.400 and 0.135 optical density units for PLAP A and PLAP C, respectively.

\section{CORRELATION BETWEen PLAP A AND C IN PATIENTS WITH CANCER}

The correlation between PLAP A and C in patients with ovarian cancer $(\mathrm{n}=397, \mathrm{r}=0.18, \mathrm{p}<0.001)$ was poorer than that for the blood donors, although still significant.

\section{PLAP A, PLAP C AND CA 125 \\ CONCENTRATIONS}

The proportion of samples with raised values of PLAP A, PLAP C, and CA125 are shown in table 1. Patients were divided according to the Féderation International de Gynecologie et Obstetrique (FIGO) stage and histopathology. Abnormal values were seen in all stages, but were more numerous in advanced (FIGO stages III and IV) disease.

The sensitivity, specificity, and accuracy of PLAP A, PLAP C, and CA125 for each stage and histopathological type are shown in table 2 . Using these criteria PLAP A was more sensitive but less specific than PLAP C for stages III and IV disease, although both performed less well than CA125.

The sensitivity, specificity, accuracy and predictive values of a positive result (PVP) and of a negative result (PVN) for each marker are shown in table 3: all three markers were tested in all 397 samples. This would be the case in a prospective analysis of all sample results.

Table 4 shows the above indices when the combination of all three markers are considered together; A

Table 1 Proportion of samples with raised marker values

\begin{tabular}{|c|c|c|c|c|c|}
\hline & \multirow[b]{2}{*}{ No of subjects } & \multirow[b]{2}{*}{ No of samples } & \multicolumn{3}{|c|}{ No of sample results evaluated ( $T P$ and $F P$ ) } \\
\hline & & & PLAP A $(O D>0.4)$ & $P L A P C(O D>0.15)$ & CA125 $(35 \mathrm{U} / \mathrm{ml})$ \\
\hline Blood donors & 387 & 387 & $18(5 \%)$ & $5(1 \%)$ & \\
\hline $\begin{array}{l}\text { Patients: } \\
\text { Stage I: } \\
\text { Serous } \\
\text { Mucinous } \\
\text { PDA }\end{array}$ & $\begin{array}{l}5 \\
1 \\
1\end{array}$ & $\begin{array}{r}20 \\
5 \\
3\end{array}$ & $\begin{array}{r}11 \\
2 \\
1\end{array}$ & $\begin{array}{l}9 \\
0 \\
2\end{array}$ & $\begin{array}{l}1 \\
0 \\
0\end{array}$ \\
\hline $\begin{array}{l}\text { Stage II: } \\
\text { Serous } \\
\text { Mucinous }\end{array}$ & $\begin{array}{l}4 \\
1\end{array}$ & $\begin{array}{r}19 \\
3\end{array}$ & $\begin{array}{l}6 \\
2\end{array}$ & $\begin{array}{l}2 \\
0\end{array}$ & $\begin{array}{l}4 \\
0\end{array}$ \\
\hline $\begin{array}{l}\text { Stage III } \\
\text { Serous } \\
\text { Mucinous } \\
\text { PDA }\end{array}$ & $\begin{array}{r}40 \\
3 \\
12\end{array}$ & $\begin{array}{r}204 \\
12 \\
47\end{array}$ & $\begin{array}{r}122 \\
9 \\
21\end{array}$ & $\begin{array}{r}81 \\
6 \\
5\end{array}$ & $\begin{array}{r}108 \\
3 \\
22\end{array}$ \\
\hline $\begin{array}{l}\text { Stage IV: } \\
\text { Serous } \\
\text { PDA }\end{array}$ & $\begin{array}{r}15 \\
5\end{array}$ & $\begin{array}{l}64 \\
20\end{array}$ & $\begin{array}{l}44 \\
15\end{array}$ & $\begin{array}{r}24 \\
4\end{array}$ & $\begin{array}{l}44 \\
14\end{array}$ \\
\hline Total & 87 & 397 & $233(59 \%)$ & $133(33 \cdot 5 \%)$ & $196(49 \%)$ \\
\hline
\end{tabular}

PDA-Poorly differentiated adenocarcinoma. 
Combined ELISA for monitoring ovarian cancer

Table 2 Marker performance as assessed by histopathology and FIGO staging

\begin{tabular}{|c|c|c|c|c|}
\hline Stage (FIGO) & $\begin{array}{l}\text { Tumour } \\
\text { marker }\end{array}$ & $\begin{array}{l}\text { Sensitivity } \\
(\%)\end{array}$ & $\begin{array}{l}\text { Specificity } \\
(\%)\end{array}$ & $\begin{array}{l}\text { Accuracy } \\
(\%)\end{array}$ \\
\hline I & $\begin{array}{l}\text { PLAP A } \\
\text { PLAP C } \\
\text { CA125 }\end{array}$ & $\begin{array}{l}20 \\
60 \\
20\end{array}$ & $\begin{array}{r}43 \\
65 \\
100\end{array}$ & $\begin{array}{l}39 \\
64 \\
86\end{array}$ \\
\hline II & $\begin{array}{l}\text { PLAP A } \\
\text { PLAP C } \\
\text { CA125 }\end{array}$ & $\begin{array}{r}0 \\
0 \\
100\end{array}$ & $\begin{array}{l}60 \\
90 \\
90\end{array}$ & $\begin{array}{l}55 \\
91 \\
91\end{array}$ \\
\hline III & $\begin{array}{l}\text { PLAP A } \\
\text { PLAP C } \\
\text { CA125 }\end{array}$ & $\begin{array}{l}61 \\
37 \\
70\end{array}$ & $\begin{array}{l}51 \\
69 \\
96\end{array}$ & $\begin{array}{l}58 \\
46 \\
78\end{array}$ \\
\hline IV & $\begin{array}{l}\text { PLAP A } \\
\text { PLAP C } \\
\text { CA125 }\end{array}$ & $\begin{array}{l}78 \\
38 \\
83\end{array}$ & $\begin{array}{l}67 \\
93 \\
93\end{array}$ & $\begin{array}{l}76 \\
48 \\
85\end{array}$ \\
\hline$I+I I$ & $\begin{array}{l}\text { PLAP A } \\
\text { PLAP C } \\
\text { CA125 }\end{array}$ & $\begin{array}{l}14 \\
43 \\
43\end{array}$ & $\begin{array}{l}51 \\
77 \\
95\end{array}$ & $\begin{array}{l}46 \\
72 \\
88\end{array}$ \\
\hline III + IV & $\begin{array}{l}\text { PLAP A } \\
\text { PLAP C } \\
\text { CA125 }\end{array}$ & $\begin{array}{l}66 \\
37 \\
74\end{array}$ & $\begin{array}{l}53 \\
73 \\
96\end{array}$ & $\begin{array}{l}63 \\
46 \\
80\end{array}$ \\
\hline $\begin{array}{l}\text { Histological typ } \\
\text { (stages I-IV): } \\
\text { Serous }\end{array}$ & $\begin{array}{l}\text { PLAP A } \\
\text { PLAP C } \\
\text { CA125 }\end{array}$ & $\begin{array}{l}65 \\
42 \\
74\end{array}$ & $\begin{array}{l}51 \\
71 \\
95\end{array}$ & $\begin{array}{l}60 \\
51 \\
81\end{array}$ \\
\hline $\begin{array}{l}\text { Mucinous } \\
\text { Poorly different }\end{array}$ & $\begin{array}{l}\text { PLAP A } \\
\text { PLAP C } \\
\text { CA125 } \\
\text { adenocarci } \\
\text { PLAP A } \\
\text { PLAP C } \\
\text { CA125 }\end{array}$ & $\begin{array}{r}71 \\
14 \\
43 \\
\text { 10ma: } \\
63 \\
21 \\
73\end{array}$ & $\begin{array}{r}38 \\
62 \\
100 \\
\\
65 \\
95 \\
95\end{array}$ & $\begin{array}{l}50 \\
45 \\
80 \\
\\
64 \\
44 \\
80\end{array}$ \\
\hline
\end{tabular}

Table 3 Individual CA125, PLAP A, and PLAP C results

\begin{tabular}{llrr}
\hline & CA125 & \multicolumn{1}{l}{ PLAP A } & \multicolumn{1}{l}{ PLAPC } \\
\hline Sensitivity & $190 / 262(73 \%)$ & $169 / 262(65 \%)$ & $98 / 262(37 \%)$ \\
Specificity & $130 / 135(96 \%)$ & $71 / 135(53 \%)$ & $99 / 135(73 \%)$ \\
Accuracy & $320 / 397(81 \%)$ & $240 / 397(60 \%)$ & $197 / 397(50 \%)$ \\
PVP & $190 / 196(97 \%)$ & $169 / 233(73 \%)$ & $98 / 133(74 \%)$ \\
PVN & $130 / 201(65 \%)$ & $71 / 164(43 \%)$ & $99 / 264(38 \%)$ \\
\hline
\end{tabular}

shows positive marker state where one or more than one marker in the panel was increased, and B shows the same indices when PLAP was tested only in the samples which were CA125 negative (so called "series testing").

SERIAL ANTIGEN TITRES IN TWO PATIENTS

Two patients were chosen after analysis of their serial antigen titres, (fig 2) to illustrate retrospectively if
PLAP A and PLAP C had been useful for predicting relapse. In case 1 CA 125 had been negative until well after clinically evident relapse, and in case 2 an increase in CA125, although preceding relapse, was a late event. An increase in PLAP A in case 1 and an increase in PLAP C in case 2 would have been earlier predictors of relapse. Both patients were followed up after a positive second look laparotomy. Case 1 was receiving chlorambucil when each sample was taken and case 2 received three cycles of Cis-platinum throughout the blood sampling period.
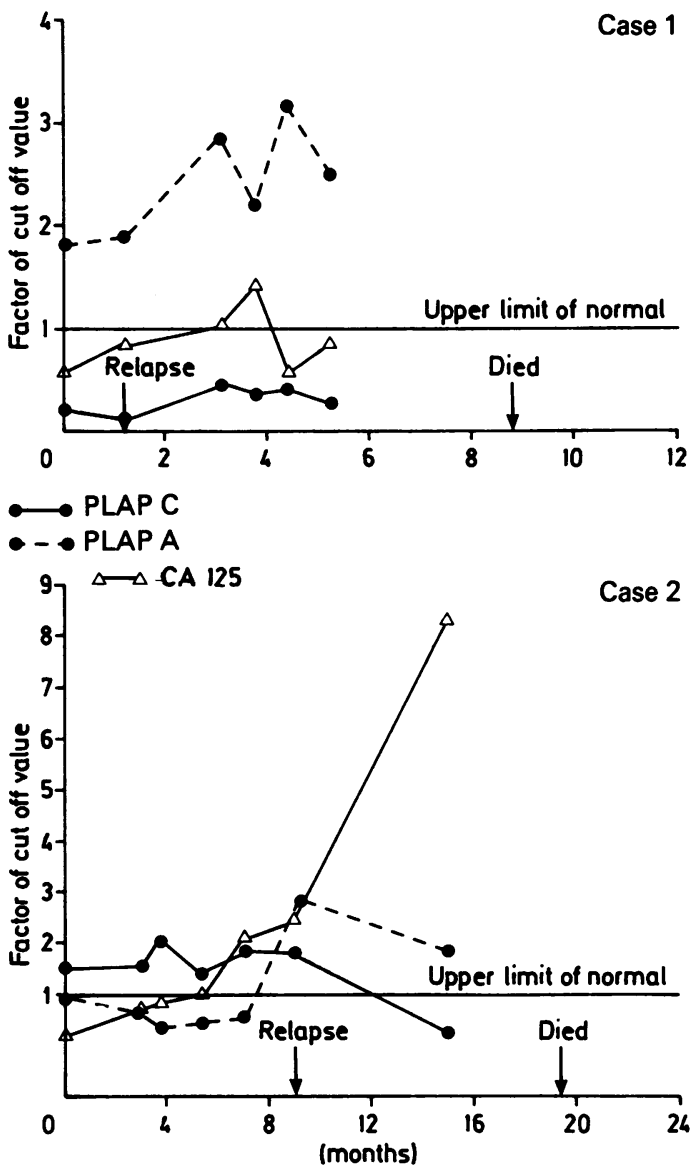

Fig 2 Case 1: stage III adenocarcinoma. Case 2: stage III serous papillary adenocarcinoma.

Table 4 CA125, PLAP A, and PLAP C panel results

\begin{tabular}{llllll}
\hline & Sensitivity & Specificity & Accuracy & $P V P$ & PVN \\
\hline $\begin{array}{l}\text { A: CA125, PLAP A and PLAP C } \\
\text { where } \geqslant 1 \text { marker is positive }\end{array}$ & $43 / 261(93 \%)$ & $57 / 136(42 \%)$ & $300 / 397(76 \%)$ & $243 / 322(75 \%)$ & $57 / 75(76 \%)$ \\
$\begin{array}{l}\text { B: PLAP testing in series on a } \\
\text { negative CA125 result }\end{array}$ & $53 / 71(75 \%)$ & $57 / 130(44 \%)$ & $110 / 201(55 \%)$ & $53 / 126(42 \%)$ & $57 / 75(76 \%)$ \\
\hline
\end{tabular}




\section{Discussion}

Determination of both PLAP A and C in a combined assay has several advantages over separate assays. These include reduced expense (in particular halved monoclonal antibody costs) and reduced operator time and error due to sampling variation. The correlation between the combined and discrete PLAP C assay was high, supporting the use of the combined assay. The gradient of the slope was greater than 1.0 , however, for which the reasons are unclear. The greater absorbance in the combined assay was not due to residual p-nitrophenyl phosphate substrate, which showed zero absorbance at wavelengths greater than $470 \mathrm{~nm}$. In the combined assay the catalytic reaction may have induced a conformational change in PLAP which results in enhanced recognition and binding by the rabbit anti-human PLAP.

The data show that PLAP A and PLAP C assays, individually and in combination, are insufficiently sensitive and specific (tables 2 and 3 ) for the management of women with epithelial ovarian cancer. Several reasons for the failure of PLAP to fulfil expectations may be postulated. Changes in antigen expression during disease progression and increasing tumour dedifferentiation are complex, substantiated by the lack of close correlation we have found between PLAP A and PLAP C in cancer patients when compared with normal controls. These findings contrast with reports from another group who used a different monoclonal antibody raised against PLAP. ${ }^{14}$

Numerous factors influence the expression of PLAP, including smoking, which induces PLAP-like alkaline phosphatase synthesis and secretion by lung alveoli. ${ }^{15}$ H17E2 recognises this isoenzyme, ${ }^{16}$ which may in part account for a high proportion of false positive results in our series of patients. Whether a "smoking effect" was a source of error in this series is uncertain. The control sera showed a significant increase in the reference interval only in the PLAP C assay; in the patients' sera many more false positive results were seen with PLAP A than with the PLAP C assay. For PLAP C the use of a correction factor based on observations in the large control group might reasonably be expected to have reduced the false positive results associated with smoking. Unfortunately, information on the smoking habits in most patients was unobtainable, hence the effect of smoking on the patients' PLAP values could not be assessed properly.

PLAP has not previously been evaluated in terms of sensitivity, specificity, accuracy and predictive power, ${ }^{16}$ although numerous reports advocate its use as a tumour marker in ovarian cancer. ${ }^{5-81114}$ When results for PLAP A and PLAP C were combined with CA125 results the overall sensitivity increased from
$73 \%$ with CA125 alone to $93 \%$ with all three markers, where at least one gave a positive result (table 4a). Combining results in this way, however, resulted in a considerable loss of specificity, from $96 \%$ for CA125 alone to $42 \%$ for the combined results. This loss of specificity is better seen in terms of the relative predictive powers of the test. The PVP of CA125 alone was $97 \%$ with a PVN of $65 \%$ (table 3), whereas the combined results showed a fall of PVP to $75 \%$ and only a relatively small rise in PVN to $76 \%$ (tables $4 a$ and $b$ ).

PLAP may be assayed in series ${ }^{17}$ with CA125. This reduces the total number of PLAP assays required as only CA125-negative samples would require retesting, allowing the PVP of CA125 alone to be retained. Serial analysis of the patients' data (table 4b) showed that the use of PLAP A and PLAP C on samples negative for CA125 $(n=201)$ gave a PVP of both assays together of only $42 \%$, with PVN remaining unchanged at $76 \%$. It is clear, therefore, that assay of PLAP A and PLAP $C$ did not add significantly to the predictive value of CA125 in these negative samples in which the active disease prevalence, as assessed clinically, was 71/201 $(35 \%)$.

These data indicate that PLAP, as measured with this monoclonal antibody, confused the interpretation of CA125 results in this cohort of patients. CA125 assay used on its own would seem to be more helpful in clinical decision making. The results of this study agree with those of a recent report by Haije et al,${ }^{18}$ who also assayed PLAP activity and concentration by immunoreactivity, but found neither to be useful for general patient follow up and management.

Tucker $e t$ al have found determination of PLAP activity using H17E2 useful in the follow up of testicular germ cell tumours, particularly seminomas. ${ }^{10}$ The applicability of the simple combined assay deserves to be tested in this and possibly other cancers.

The combined assay, using a more specific monoclonal antibody, one which does not react with PLAP induced by smoking, ${ }^{6}$ may prove useful in the follow up of patients with ovarian cancer. Increased specificity would then be obtained, possibly at the expense of sensitivity - an acceptable modification in the context of a panel of markers where specificity of each marker is the most important criterion.

Although measurement of PLAP was not found to be generally helpful, a few patients may have benefited from additional PLAP assay (fig 2). It is impossible at this stage to judge which patients will benefit most from prospective serial measurement of PLAP. Appropriate patient selection is essential if PLAP is to be of use in future as an adjunct in monitoring ovarian cancer.

Unfortunately, insufficient preoperative samples were available in this study to assess the value of PLAP 
assays in the untreated patient. Preoperative measurement of PLAP may provide a helpful indicator of patients who will benefit from further serial measurement in a manner analogous to CA125 where assay at the time the disease presents helps in the selection of "secretors". 19

Despite initial promising investigations of PLAP as a tumour marker in ovarian cancer this study and others ${ }^{1820}$ have failed to corroborate them. Work is currently under way using various monoclonal antibodies to investigate further the PLAP molecules and epitopes in conjunction with assay development for other promising markers such as mucin antigens. ${ }^{13}$

We thank Dr D Tucker of the Imperial Cancer Research Fund for kindly supplying H17E2 monoclonal antibody and Dr J Gillon of South East Scotland Blood Transfusion Service for his cooperation in the collection of samples from blood donors. This work was supported by the Melville Trust (Grant No 918600) and the Royal Infirmary of Edinburgh Cancer Research Endowment Fund. We are also grateful to Mrs E Ward for typing the manuscript.

\section{References}

1 Bhattacharya M, Chatterjee SK, Barlow JJ. Ovarian tumour antigens and other tumour markers. In: Hudson $\mathrm{CN}$, ed. Ovarian cancer. Oxford: Oxford University Press, 1985:169-89.

2 Ward BG, Shepherd JH. The role of monoclonal antibodies in diagnosis and investigation of ovarian cancer. In: Blackledge G, Chan KK, eds. Management of ovarian cancer. London: Butterworths, 1986:169-89.

3 Bast RC, Klug TL, St John E, et al. A radioimmunoassay using a monoclonal antibody to monitor the course of epithelial ovarian cancer. $N$ Engl J Med 1983;309:883-7.

4 Fishman WH, Inglis NI, Stalbach LL, et al. Serum ALP isoenzyme of human neoplastic cell origin. Cancer Res 1968;28:150.

5 Muensch HA, Maslow WC, Azama F, Bertrand M, Dewhurst P, Hartman B. Placental-like alkaline phosphatase. Re-evaluation of the tumour marker with exclusion of smokers. Cancer 1986;58:1689-94.

6 McLaughlin PJ, Gee H, Johnson PM. PLAP in pregnancy and malignancy plasma: specific estimation using a monoclonal antibody in a solid-phase enzyme immunoassay. Clin Chim Acta 1983;130:199-209.
7 Pollet DE, Nouwen EJ, Schelstraete JB, et al. Enzyme-antigen immunoassay for hPLAP in serum and tissue extracts and its application as a tumour marker. Clin Chim Acta 1985;31:41-5.

8 De Groote G, De Waele P, Van de Voorde A, De Broe ME, Fiers W. Use of monoclonal antibodies to detect human placental alkaline phosphatase. Clin Chem 1983;29:115-9.

9 Maslow WC, Muensch HA, Azama F, Schneider AS. Sensitive fluorimetry of heat stable ALP (Regan enzyme) activity in serum from smokers and non-smokers. Clin Chem 1983;29: 160-263.

10 Tucker DF, Oliver RTD, Travers P, Bodmer WF. Serum marker potential of PLAP-like activity in testicular germ cell tumours evaluated by $\mathrm{H} 17 \mathrm{E} 2$ monoclonal antibody assay. $\mathrm{Br} \mathrm{J}$ Cancer 1985;51:631-9.

11 Davies JO, Davies ER, Howe K, et al. Practical applications of a monoclonal antibody $\left(\mathrm{NDOG}_{2}\right.$ ) against PLAP in ovarian cancer. J R Soc Med 1985;78:899-905.

12 Travers P, Bodmer WF. Preparation and characterisation of monoclonal antibodies against PLAP and other human trophoblast associated determinants. Int J Cancer 1984;33: 633-41.

13 Dhokia B, Canney PA, Pectasides D, et al. A new immunoassay using monoclonal antibodies HMFG1 and HMFG2 together with an existing marker CA125 for the serological detection and management of epithelial ovarian cancer. $\mathrm{Br} J$ Cancer 1986;54:891-5.

14 Millan JL, Stigbrand T. "Sandwich" enzyme immunoassay for PLAP. Clin Chem 1981;27:2014-18.

15 Williams GH, McLaughlin PJ, Johnson PM. Tissue origin of serum placental-like alkaline phosphatase in cigarette smokers. Clin Chim Acta 1986;155:329-334.

16 Ward BG, Cruickshank DJ, Tucker DF, Love S. Independent expression in serum of three tumour-associated antigens: CA125, placental alkaline phosphatase and HMFG2 in ovarian carcinoma. Br J Obstet Gynecol 1987;94:696-8.

17 Galen RS, Gambino SR. Combinations testing - multiple testing. In: Beyond normality. New York: John Wiley, 1975:42-8.

18 Haije WG, Van Driel J, Van der Burg MEL. Catalytic and immunologic activities of PLAP in clinical studies. The value of PLAP in follow up of ovarian cancer. Clin Chim Acta 1987;165:165-75.

19 Cruickshank DJ, Fullerton WT, Klopper A. The clinical significance of pre-operative serum CA125 in ovarian cancer. $B r J$ Obstet Gynecol 1987;94:692-5.

20 Vergote I, Onsrud M, Nustad K. PLAP as a tumor marker in ovarian cancer. Obstet Gynecol 1987;69:228-32.

Requests for reprints to: Dr J E Roulston, Department of Clinical Chemistry, Royal Infirmary, Edinburgh EH3 9YW, Scotland. 